\title{
AGROINDUSTRI TEH DAUN GAHARU DI KELURAHAN SIDOMULYO BARAT KECAMATAN TAMPAN PEKANBARU (STUDI KASUS CV. GAHARU PLAZA INDONESIA)
}

\author{
Agroindustry of Agarwood Leaf Tea in Kelurahan Sidomulyo Barat Kecamatan \\ Tampan Pekanbaru (Case Study of CV. Gaharu Plaza Indonesia)
}

\author{
Chandra Leonardo dan Fahrial \\ Program Studi Agribisnis, Fakultas Pertanian Universitas Islam Riau \\ J1. Kaharuddin Nasution No.113 Pekanbaru. 28284 \\ Email: leonardochandra3@gmail.com \\ [Diterima: Januari 2020; Disetujui: April 2020]
}

\begin{abstract}
Agarwood leaf Aquilaria malaccensis Lamk is used as a raw material in the agroindustry of agarwood leaf tea. This study aimed to analyze the production cost, revenue, profit, efficiency, and value-added. This research used a survey method as a case study of the CV. Gaharu Plaza Indonesia which was conducted in Sidomulyo Barat Village, Tampan District, Pekanbaru. The results of the study showed that the agarwood leaf tea agroindustry by CV. Gaharu Plaza Indonesia is a small business or micro business. The technology in processing agarwood leaf tea is semi-mechanical and has a home industry food production certificate, a small trade business permit, and the health department. The raw material used for the one-time production process for the agro-industry of agarwood leaf tea was as much as $4 \mathrm{~kg}$ of agarwood leaves, with supporting materials such as jasmine flowers, tea bags, packaging boxes, standing pouch packaging, transparent roll plastic, and packaging labels. Production cost was IDR 1.715.894, the income of IDR 4.250.000, net profit of IDR 2.534.106, the added value of processing aloes into aloes leaf tea was IDR 13.269. The RCR value was 2,48 with the criteria RCR value > 1 is profitable and feasible to be developed.
\end{abstract}

Keywords: Agroindustry, Agarwood leaf tea, Value added

\begin{abstract}
ABSTRAK
Daun Gaharu jenis Aquilaria malaccensis Lamk digunakan sebagai bahan baku pada agroindustri teh daun gaharu. Penelitian ini bertujuan untuk menganalisis: Biaya produksi, Pendapatan, Keuntungan, Efisiensi dan Nilai tambah (Value Added). Penelitian ini menggunakan metode survey, studi kasus pada CV. Gaharu Plaza Indonesia yang dilaksanakan di Kelurahan Sidomulyo Barat Kecamatan Tampan Pekanbaru. Hasil dari penelitian menunjukan bahwa usaha agroindustri teh daun gaharu oleh CV. Gaharu Plaza Indonesia merupakan usaha kecil atau usaha mikro. Teknologi dalam pengolahan teh daun gaharu adalah semi mekanis, sudah memiliki sertifikat produksi pangan industri rumah tangga, izin usaha perdagangan kecil dan dinas kesehatan. Bahan baku yang digunakan untuk satu kali proses produksi untuk agroindustri teh daun gaharu adalah daun gaharu sebanyak $4 \mathrm{~kg}$, dengan bahan penunjang berupa bunga melati, kantung bag teh celup, kotak kemasan, kemasan standing pouch, plastik rool transparan dan label kemasan. Biaya produksi sebesar Rp.1.715.894, pendapatan Rp.4.250.000, keuntungan bersih sebesar Rp.2.534.106, nilai tambah dari pengolahan daun gaharu menjadi teh daun gaharu sebesar Rp.13.269. Untuk nilai RCR sebesar 2,48 dengan kriteria nilai RCR > 1 menguntungkan dan layak untuk dikembangkan.
\end{abstract}

Kata kunci: Agroindustri, Teh Daun Gaharu, Nilai Tambah

\section{PENDAHULUAN}

Indonesia merupakan negara agraris yang sangat besar potensinya dalam bidang pertanian. Salah satunya yaitu dengan usaha pengolahan hasil kehutanan yang dapat mengembangkan perekonomian.

Hasil kehutanan terbagi dua yaitu hasil hutan kayu dan hasil hutan bukan kayu (HHBK). Yang menjadi fokus pengembangan 
saat ini adalah hasil hutan bukan kayu (HHBK).

Menurut Peraturan Menteri Kehutanan Nomor 35/MENHUT-II/2007 telah ditetapkannya jenis-jenis HHBK yang terdiri dari 557 spesies tumbuhan dan hewan (Anonim, 2007). Hasil hutan bukan kayu memiliki potensi besar yang terpendam di hutan alam serta belum digali untuk dikelola secara lestari sampai saat ini. Salah satu hasil hutan bukan kayu yang menjadi prioritas pengembangan pada saat ini adalah gaharu.

Gaharu awalnya memiliki manfaat yang terbatas hanya untuk wewangian tubuh, ruangan dan kelengkapan upacara ritual keagamaan masyarakat Hindu dan Islam. Produk gaharu selain dibutuhkan sebagai bahan industri parfum dan komestika, juga banyak dibutuhkan sebagai bahan obat herbal, untuk pengobatan stress, asma, rheumatik, radang ginjal dan lambung, bahan anti biotik TBC, serta tumor dan kanker (Sumarna, 2007)

Di Indonesia, persediaan pohon ini diperkirakan mencapai 1,87 pohon per ha di Sumatera, 3,37 pohon per ha di Kalimantan, 4,33 pohon per ha di Papua. Tanaman gaharu merupakan salah satu komoditas yang memiliki nilai ekonomi tinggi dan menghasilkan gubal berupa kayu yang berasal dari pembusukan akibat aktivitas mikroba. (Mega dkk, 2012).

Selain gubal gaharu, penelitian berkembang pada daun gaharu karena mengingat masa tunggu panen gubal gaharu tergolong lama yaitu berkisar 3-4 tahun setelah terifeksi jamur, sedangkan daun gaharu yang berusia 1,5 - 3 tahun sudah baik dan sangat potensial untuk dijadikan bahan baku dalam pembuatan teh gaharu. Daun gaharu diduga mengandung senyawa metabolit sekunder yang lebih tinggi akibat meningkatnya proses metabolisme pohon gaharu yang terinfeksi jamur. Melalui proses metabolisme, senyawasenyawa tersebut terdistribusi ke bagian pohon lain terutama daun. Hal ini menyebabkan daun gaharu memiliki potensi sebagai antioksidan (Nasution et. al. 2015).

Teh daun gaharu berasal dari daun gaharu (Aquilaria malaccensis Lamk). Daun gaharu yang dijadikan teh ternyata memiliki manfaat bagi orang yang mengkonsumsinya. Manfaat dari mengkonsumsi teh daun gaharu yaitu sebagai anti asmatik, stimulan kerja saraf, obat kanker, penghilang stress, obat malaria, anti mikrobia, obat sakit perut, penghilang rasa sakit, obat ginjal, obat lever dan obat diare (Sukandar, 2010).

Diprovinsi Riau terdapat sebuah perusahan yang merupakan satu-satunya industri pengolahan daun gaharu menjadi the daun gaharu yaitu CV. Gaharu Plaza Indonesia. Teh daun gaharu memiliki keunggulan dan keunikannya tersendiri, teh daun gaharu memiliki aroma yang khas berbeda dengan aroma teh yang berasal dari daun teh Camellia sinensis, dari segi bentuk nya teh dari daun gaharu berwarna kekuningan dan agak kelihatan bening, dari segi rasa memiliki rasa yang alami atau original dan mempunyai daya tarik tersendiri, dilihat dari manfaatnya yang begitu bagus untuk kesehatan.

Pada CV. Gaharu Plaza Indonesia, pembuatan teh daun gaharu diolah dengan cara manual dan menggunakan mesin sederhana, setelah pembelian daun dari para petani gaharu, daun gaharu dibersihkan oleh para pekerja, selanjutnya pemisahan (sortasi) daun yang masih bagus dengan daun yang cacat/tidak digunakan, setelah itu dilakukan pengeringan dengan mesin pengering, setelah daun kering daun dicacah menggunakan mesin glinder dan mesin glinding perbedaannya yaitu dari kapasitas dan kecepatan dalam memotong daun, untuk mesin glinder daun dipotong dengan ukuran kasar sedangkan untuk mesin glinding daun dipotong dengan ukuran halus seperti bubuk.

Usaha CV. Gaharu Plaza Indonesia merupakan usaha yang memproduksi teh daun gaharu dalam kemasan, dalam usaha ini penting untuk diketahui biaya produksi yang dikeluarkan untuk memproduksi teh daun gaharu dan juga mengetahui pendapatan yang diperoleh pengusaha untuk mengoptimalkan keuntungan yang diperolehnya.

\section{PERUMUSAN MASALAH}

adalah:

Perumusan masalah penelitian ini

1. Bagaimana Karakteristik Pengusaha dan Profil usaha Agroindustri Teh Daun Gaharu pada CV. Gaharu Plaza Indonesia?

2. Bagaimana ketersediaan bahan baku, penggunaan bahan penunjang, teknologi pengolahan, penggunaan tenaga kerja dan proses produksi Agroindustri Teh Daun Gaharu pada CV. Gaharu Plaza Indonesia? 
3. Berapa biaya Produksi, pendapatan, keuntungan, efisiensi dan nilai tambah Agroindustri Teh Daun Gaharu pada CV. Gaharu Plaza Indonesia?

\section{TUJUAN PENELITIAN}

Tujuan penelitian ini adalah:

1. Menganalisis karakteristik pengusaha dan profil usaha Agroindustri Teh Daun Gaharu pada CV. Gaharu Plaza Indonesia.

2. Menganalisis penggunaan bahan baku, bahan penunjang, teknologi pengolahan, penggunaan tenaga kerja dan proses produksi Agroindustri Teh Daun Gaharu pada CV. Gaharu Plaza Indonesia.

3. Menganalisis biaya produksi, pendapatan, keuntungan, efisiensi dan nilai tambah Agroindustri Teh Daun Gaharu pada CV. Gaharu Plaza Indonesia.

\section{METODE PENELITIAN}

\section{Metode, Tempat dan Waktu Penelitian}

Penelitian dilakukan dengan metode studi kasus pada CV. Gaharu Plaza Indonesia dengan jenis usaha Agroindustri Teh Daun Gaharu di Kelurahan Sidomulyo Barat Kecamatan Tampan Pekanbaru. Penelitian ini dilakukan selama 6 bulan yaitu mulai dari bulan Juli sampai bulan Desember 2019 yang meliputi kegiatan persiapan, (pembuatan proposal, seminar, perbaikan), pelaksanaan (pengumpulan data, tabulasi data, dan analisis data), perumusan hasil (draf laporan, seminar, perbaikan, perbanyak laporan).

\section{Teknik Pengambilan Sampel}

Populasi dalam penelitian ini adalah pengusaha agroindustri teh daun gaharu di Kelurahan Sidomulyo Barat Kecamatan Tampan Pekanbaru. Berdasarkan survei dilapangan pengambilan sampel dalam penelitian ini menggunakan sensus.

\section{Teknik Pengambilan Data}

Teknik pengumpulan data adalah dengan wawancara yang dilakukan langsung dengan pemilik perusahaan dengan menggunakan kuisioner yang telah dipersiapkan sebelumnya. Dari hasil wawancara akan diperoleh data primer yang meliputi: identitas pengusaha, nama agroindustri, mata pencaharian, umur pengusaha, tingkat pendidikan, jumlah anggota keluarga, biaya produksi, pendapatan, keuntungan, bahan baku, bahan penunjang, jumlah tenaga kerja, upah tenaga kerja, penggunaan alat, Pengalaman berusaha, dan jumlah tanggungan keluarga.

Data sekunder diperoleh dari instansi terkait, yang dianggap perlu untuk menunjang penelitian ini meliputi: keadaan geografis daerah penelitian, jumlah penduduk, tingkat pendidikan penduduk, dan keadaan sosial ekonomi penduduk setempat dan data lainnya yang ada hubungannya dengan penelitian ini.

\section{Konsep Operasional}

1. Gaharu adalah tanaman yang dibudidayakan oleh petani dan dipanen setelah berumur kurang lebih 25 tahun untuk mendapatkan gubalnya sedangkan bagian tanamannya yang lain seperti daun yang dimanfaatkan untuk bahan agroindustri dapat dipanen pada saat tanaman sudah berumur kurang lebih 3 tahun.

2. Agroindustri teh daun gaharu adalah pengolahan dari bahan baku yang berasal dari daun gaharu menjadi teh daun gaharu siap untuk dipasarkan.

3. Pengusaha teh daun gaharu adalah orang yang memproduksi atau mengusahakan daun gaharu menjadi teh gaharu di Sidomulyo Barat Kecamatan Tampan Pekanbaru.

4. Bahan Baku adalah bahan dasar yang dibutuhkan dalam pembuatan teh daun gaharu yaitu daun gaharu.

5. Teh daun gaharu adalah produk olahan dari daun gaharu kemudian dikemas dalam kantung (bag) yang terbuat dari filter paper (kantong kertas celup dari bahan tissue yang tahan panas)

6. Bahan penunjang teh daun gaharu merupakan input produksi selain bahan baku (daun gaharu) yang diperlukan dalam proses produksi teh daun gaharu, meliputi: bunga melati (sebagai penguat bau tehnya), kotak kemasan, kemasan standing pouch, kantong bag, listrik (kwh).

7. Harga beli daun gaharu adalah nilai beli bahan baku (daun gaharu) untuk satu kali periode produksi ( $\mathrm{Rp}$ /proses produksi).

8. Tenaga kerja adalah jumlah jam kerja perhari orang yang bekerja dalam proses produksi teh daun gaharu (HOK/Proses Produksi).

9. Upah Tenaga Kerja merupakan nilai/sejumlah uang yang diterima 
karyawan dalam proses produksi (Rp/HOK/proses produksi).

10. Biaya Produksi teh daun gaharu adalah biaya yang dikeluarkan baik tetap maupun biaya variabel dalam proses produksi sesperti biaya peralatan produksi (penyusutan), biaya tenaga kerja dalam setiap proses produksi pada agroindustri teh daun gaharu ( $\mathrm{Rp} /$ proses produksi).

11. Biaya tetap biaya yang dikeluarkan dalam usaha agroindustri teh daun gaharu seperti penyusutan alat, bahan bakar dan kayu (Rp/proses produksi).

12. Biaya variabel adalah biaya yang dikeluarkan dalam usaha agroindustri teh daun gaharu secara tunai seperti biaya bahan baku, bahan penunjang dan tenaga kerja luar perusahaan (Rp/proses produksi).

13. Harga jual teh daun gaharu adalah suatu nilai tukar yang bisa disamakan dengan uang atau barang lain.

14. Pendapatan teh daun gaharu adalah jumlah produksi yang dihasilkan dikalikan dengan harga jual produk dalam satu kali proses produksi pada agroindustri teh gaharu (Rp/kemasan/proses produksi).

15. Keuntungan teh daun gaharu adalah selisih antara pendapatan kotor dengan total biaya produksi pada agroindustri teh daun gaharu (Rp/proses produksi).

16. Efesiensi usaha teh daun gaharu adalah ukuran keberhasilan usaha, perbandingan antara pendapatan kotor dengan biaya produksi pada agroindustri teh daun gaharu.

17. Nilai tambah teh daun gaharu adalah nilai yang didapatkan dari pengurangan nilai produk dengan nilai input bahan baku dan sumbangan input-input lainnya (Rp/gram).

\section{Analisis Data}

Data yang diperoleh dari hasil penelitian diolah dan disetarakan untuk dianalisis sesuai dengan tujuan penelitian.

\section{Analisis Karakteristik Pengusaha dan Profil Usaha Teh Gaharu}

Untuk memperjelas dalam penelitian ini dapat dilihat karakteristik pengusaha teh daun gaharu dan profil usaha agroindustri Teh Daun Gaharu di Kelurahan Sidomulyo Kecamatan Tampan Pekanbaru maka dilakukan secara deskriptif kualitatif, yaitu menggambarkan tentang karakteristik pengusaha teh daun gaharu meliputi: umur, tingkat pendidikan, pengalaman usaha, dan jumlah tanggungan keluarga. Selanjutnya profil usaha agroindustri teh daun gaharu.

\section{Analisis proses produksi Teh Daun Gaharu}

Analisis yang digunakan untuk mengetahui penggunaan bahan baku, bahan penunjang, teknologi pengolahan, proses produksi, dan penggunaan tenaga kerja pada usaha teh daun gaharu dianalisis dengan deskriptif kualitatif.

\section{Analisis Usaha Teh Daun Gaharu}

Dilakukan dengan analisis deskriptif kuantitatif, meliputi: biaya produksi, pendapatan, keuntungan, efisiensi dan nilai tambah, disajikan sebagai berikut:

\section{Biaya Produksi}

Biaya produksi adalah biaya yang harus dikeluarkan pengrajin atau produsen untuk membeli faktor-faktor produksi dengan tujuan menghasilkan output atau produk.

Untuk menghitung biaya produksi usaha teh gaharu maka digunakan rumus menurut Soekartawi (2010).

$\mathrm{TC}=\mathrm{TFC}+\mathrm{TVC}$.

Keterangan:

$\begin{aligned} \mathrm{TC}= & \text { Total cost } \text { (total biaya) }(\mathrm{Rp} / \mathrm{Kg} / \text { proses } \\ & \text { produksi) } \\ \mathrm{TFC}= & \text { Total fixed cost (total biaya tetap) } \\ & (\mathrm{Rp} / \mathrm{Kg} / \mathrm{proses} \text { produksi) } \\ \mathrm{TVC}= & \begin{array}{l}\text { Total variable cost (total biaya } \\ \text { variabel) }(\mathrm{Rp} / \mathrm{Kg} / \mathrm{proses} \text { produksi) }\end{array}\end{aligned}$

\section{Pendapatan}

Pendapatan usaha teh gaharu adalah perkalian antara produksi yang diperoleh dengan harga jual, dapat dituliskan sebagai berikut (Soekartawi, 2010):

TR $=$ Y.Py.

Keterangan:

$\mathrm{TR}=$ Pendapatan kotor usaha teh gaharu (Rp/proses produksi)

$\mathrm{Y}=$ Total produksi usaha teh gaharu $(\mathrm{kg} /$ proses produksi)

Py = Harga teh gaharu (Rp/gram)

\section{Keuntungan}

Pendapatan bersih dihitung dengan rumus menurut Soekartawi (2010) sebagai berikut:

$\pi=\mathrm{TR}-\mathrm{TC}$ 
Keterangan:

$$
\begin{aligned}
\pi & =\underset{\text { Pendapatan bersih }}{\text { produksi })}(\mathrm{Rp} / \text { proses } \\
\mathrm{TR} & =\begin{array}{c}
\text { Pendapatan } \\
\text { produksi })
\end{array} \\
\mathrm{TC} & =\text { Biaya Produksi }(\mathrm{Rp} / \text { proses produksi })
\end{aligned}
$$

$$
\text { Jadi didalam operasionalnya, }
$$

penerimaan bersih usaha teh celup gaharu dihitung dengan rumus sebagai berikut:

$$
\begin{aligned}
& \pi=\mathrm{Y} \cdot \mathrm{Py}-(\mathrm{X} 1 . \mathrm{Px} 1+\mathrm{X} 2 . \mathrm{Px} 2+\mathrm{X} 3 . \\
& \text { Px3) - D. }
\end{aligned}
$$

Keterangan:

$$
\begin{aligned}
& \pi \quad=\text { Penerimaan bersih usaha }(\mathrm{Rp} / \text { proses } \\
& \text { produksi) } \\
& \mathrm{Y} \quad=\text { Produksi }(\mathrm{kg} / \text { proses produksi) } \\
& \mathrm{PY}=\text { Harga Produksi ( } \mathrm{Rp} / \text { proses } \mathrm{kg}) \\
& \mathrm{X} 1=\text { Jumlah bahan baku (gaharu) }(\mathrm{kg} / \\
& \text { proses produksi) } \\
& \text { Px1 = Harga bahan baku yang digunakan } \\
& (\mathrm{Rp} / \mathrm{kg}) \\
& \mathrm{X} 2 \text { = Jumlah bahan penunjang (bunga }
\end{aligned}
$$

$$
\begin{aligned}
\mathrm{X} 3 & =\underset{\text { Jumlah tenaga kerja }}{\text { produksi })} \\
\mathrm{Px} 3 & =\underset{\mathrm{HOK} / \text { proses }}{\text { produksi })} \\
\mathrm{D} & =\text { Penyusutan }
\end{aligned}
$$

\begin{tabular}{|c|c|c|c|}
\hline I & Output, Input dan Harga & Rumus & Satuan \\
\hline 1 & Output & A & Gram \\
\hline 2 & Input & B & Gram \\
\hline 3 & Tenaga Kerja Langsung & $\mathrm{C}$ & $\mathrm{HOK}$ \\
\hline 4 & Faktor Konversi & $\mathrm{d}=\mathrm{a} / \mathrm{b}$ & \\
\hline 5 & Koefisien Tenaga Kerja Langsung & $\mathrm{e}=\mathrm{c} / \mathrm{b}$ & HOK/Gram \\
\hline 6 & Harga Output & $\mathrm{F}$ & Rp/Gram \\
\hline 7 & Upah Tenaga Kerja Langsung & G & $\mathrm{Rp} / \mathrm{HOK}$ \\
\hline II & Pendapatan dan Keuntungan & & \\
\hline 8 & Harga Bahan Baku & $\mathrm{H}$ & Rp/gram \\
\hline 9 & Sumbangan Input Lain & I & Rp/gr Output \\
\hline 10 & Nilai Output & $j=d / f$ & Rp/Gram \\
\hline \multirow{2}{*}{11} & a. Nilai Tambah & $k=j-h-i$ & Rp/Gram \\
\hline & b. Rasio Nilai Tambah & $1=\mathrm{k} / \mathrm{j} * 100$ & $\%$ \\
\hline \multirow[t]{2}{*}{12} & a. Pendapatan Tenaga Kerja & $\mathrm{m}=\mathrm{e}^{*} \mathrm{~g}$ & Rp/Gram \\
\hline & b. Pangsa Tenaga Kerja & $\mathrm{n}=\mathrm{m} / \mathrm{k} * 100$ & $\%$ \\
\hline \multirow[t]{2}{*}{13} & a. Keuntungan & $\mathrm{o}=\mathrm{k}-\mathrm{m}$ & $\mathrm{Rp}$ \\
\hline & b. Tingkat Keuntungan & $\mathrm{p}=\mathrm{o} / \mathrm{k} * 100$ & $\%$ \\
\hline III & \multicolumn{3}{|l|}{ Balas Jasa Pemilik Faktor Produksi } \\
\hline \multirow[t]{4}{*}{14} & Marjin & $q=j-h$ & Rp/Gram \\
\hline & a. Pendapatan Tenaga Kerja Langsung & $\mathrm{r}=\mathrm{m} / \mathrm{q} * 100$ & $\%$ \\
\hline & b. Sumbangan Input Lain & $\mathrm{s}=\mathrm{i} / \mathrm{q} * 100$ & $\%$ \\
\hline & c. Keuntungan Perusahaan & $\mathrm{t}=\mathrm{o} / \mathrm{q} * 100$ & $\%$ \\
\hline
\end{tabular}

\section{Efisiensi Usaha}

Efisiensi usaha teh gaharu akan dianalisis dengan menggunakan rumus Return Cost Ratio (RCR) (Soekartawi, 2010).

$R C R=\frac{\mathrm{TR}}{\mathrm{TC}}$

Keterangan:

RCR $=$ Return Cost Ratio

$\mathrm{TR}=$ Pendapatan kotor $(\mathrm{Rp} /$ proses produksi)

$\mathrm{TC}=$ Biaya Produksi $(\mathrm{Rp} /$ proses produksi)

Dengan kriteria sebagai berikut:

RCR $>1$ = Agroindustri menguntungkan

RCR $<1=$ Agroindustri tidak menguntungkan

$\mathrm{RCR}=1$ = Agroindustri impas (balik modal)

\section{Nilai Tambah}

Digunakan untuk melihat besarnya nilai tambah dari pengolahan daun gaharu menjadi teh daun gaharu yang dilakukan oleh CV. Gaharu Plaza Indonesia. Metode yang digunakan yaitu metode Hayami.

Metode menurut Hayami yang akan disajikan pada Tabel 1. 
Secara operasional perhitungan nilai tambah usaha teh gaharu diatas akan dihasilkan keterangannya sesuai dengan penelitian yang akan dilakukan, yaitu sebagai berikut:

1. Output teh gaharu (Gram) adalah produk olahan daun gaharu yang dihasilkan dalam satu kali proses produksi kemudian dikonversi ke dalam satuan per proses produksi.

2. Input (Gram) adalah bahan baku daun gaharu yang akan diolah menjadi beberapa produk olahan dalam satu kali proses produksi.

3. Tenaga kerja (HOK) adalah jumlah hari orang kerja yang digunakan untuk proses produk olahan Daun Gaharu.

4. Faktor konversi menunjukkan banyaknya output yang dihasilkan dari setiap $1 \mathrm{~kg}$ bahan baku Daun Gaharu yang digunakan.

5. Koefisien tenaga kerja (HOK/Gram) menunjukkan jumlah tenaga kerja langsung dalam proses pengolahan dari jumlah bahan baku yang digunakan.

6. Harga output (Rp/kemasan) adalah nilai jual untuk produk olahan daun gaharu.

7. Upah tenaga kerja (Rp/HOK) adalah biaya untuk tenaga kerja berdasarkan jumlah jam kerjanya.

8. Harga bahan baku daun gaharu (Rp/Gram) adalah nilai beli bahan baku daun gaharu.

9. Sumbangan Input Lain Teh Gaharu adalah rata-rata jumlah biaya untuk bahan penunjang dan dibagi dengan jumlah output teh celup yang dihasilkan.

10. Nilai output (Rp/Gram) menunjukkan nilai yang diterima dari konversi output terhadap bahan baku dengan harga output.

11. Nilai tambah (Rp) adalah selisish antara nilai output produk olahan daun gaharu dengan harga bahan baku utama daun gaharu dan bahan penunjang.

12. Rasio nilai tambah (\%) menunjukkan nilai tambah dari nilai produk.

13. Pendapatan tenaga kerja (Rp) menunjukkan upah yang diterima tenaga kerja langsung untuk mengolah satu satuan bahan baku.

14. Pangsa tenaga kerja (Rp) menunjukkan persentase pendapatan tenaga kerja dari nilai tambah yang diperoleh.

15. Keuntungan ( $\mathrm{Rp})$ menunjukkan bagian yang diterima perusahaan.
16. Tingkat keuntungan (\%) menunjukkan presentase keuntungan dari nilai produk.

17. Marjin pengolah (\%), menunjukkan kontribusi pemilik faktor produksi selain bahan baku yang digunakan dalam proses produksi.

18. Persentase pendapatan tenaga kerja langsung terhadap marjin (\%)

19. Persentase sumbangan input lain terhadap marjin (\%).

20. Persentase keuntungan perusahaan terhadap marjin $(\%)$.

\section{HASIL DAN PEMBAHASAN}

\section{Karakteristik Pengusaha dan Profil Usaha Agroindustri Teh Daun Gaharu}

Karakteristik pengusaha agroindustri Teh Daun Gaharu meliputi: umur, tingkat pendidikan, pengalaman berusaha, dan jumlah tanggungan keluarga. Diketahui bahwa umur pengusaha agroindustri teh daun gaharu berada pada kelompok umur 48 tahun dengan kategori produktif bekerja. Umur produktif pengusaha akan mempengaruhi proses adopsi suatu inovasi baru. Menurut BPS (2012), berdasarkan komposisi penduduk, umur, dikelompokkan menjadi 3 yaitu umur 0-14 tahun dianggap sebagai kelompok belum produktif, kelompok umur 15-64 tahun sebagai kelompok produktif dan kelompok umur 65 tahun keatas sebagai kelompok yang tidak lagi produktif.

Tingkat pendidikan pengusaha agroindustri teh gaharu adalah S1 di UPM (Universitas Putra Malaysia). Hal ini berarti bahwa pengusaha agroindustri teh gaharu sudah cukup tinggi dalam tingkat pendidikannya. Pengalaman berusaha merupakan salah satu faktor yang harus perhatian karena ikut mempengaruhi pengusaha untuk mengelola usahanya. Pengalaman berusaha yang dimiliki pengusaha agroindustri teh gaharu sudah cukup lama, yaitu 5 tahun. Pada umumnya pengusaha melakukan kegiatan usahanya selalu bermodalkan pada pengalaman terdahulu.

Awalnya perusahaan ini dimulai dengan nama UD. Gaharu Plaza. Bapak Budi Hamidi selaku direktur perusahaan menyiasati penggunaan mesin dengan harga yang lebih murah namun tetap memiliki fungsi yang sama serta tidak mengurangi kualitas produk yang dihasilkan. Usaha yang berjalan selama 2 tahun tersebut berkembang sangat pesat hingga 
Budi Hamidi membentuk Perusahan berbentuk Persekutuan Komanditer (CV). Perusahaan yang menjadikan ikon industri hilir produk berasaskan gaharu yang berkualitas, terjamin dan ramah lingkungan tersebut resmi didirikan pada tanggal 16 Oktober tahun 2014 dihadapan Notaris Samharnen, S.H. MH.

\section{Proses Produksi Agroindustri Teh Daun Gaharu}

Proses pengolahan daun gaharu memerlukan beberapa tahap penanganan:

1. Pencucian Daun

2. Pengeringan Daun

3. Daun dimasukkan kedalam kantong plastik

4. Pencacahan daun

5. Menambahkan bahan tambahan bunga melati yang sudah dihaluskan, dengan $4 \mathrm{~kg}$ daun kering yang sudah dicacah dimasukan bunga melati sebanyak $1,5 \mathrm{Kg}$.
6. Setelah bahan sudah tercampur merata, lalu akan dimasukan kedalam kantung bag teh celup, Setelah semua sudah masuk kedalam kantung bag

7. Penutupan kantung bag menggunakan mesin press

8. Proses pengemasan

\section{Analisis Usaha Agroindustri Teh Daun Gaharu}

Dalam mengelola atau menjalankan suatu usaha sangat penting dilakukan analisis usaha, karena dari analisis usaha ini dapat diketahui kelayakan dari usaha tersebut dan dengan analisis usaha juga dapat mengetahui dan membandingkan berapa pendapatan yang diperoleh dalam berusaha.

Tabel 1. Analisis Biaya Produksi, Pendapatan, Keuntungan dan Efisiensi Agroindustri Teh Daun Gaharu CV. Gaharu Plaza Indonesia, 2019

\begin{tabular}{|c|c|c|c|c|c|}
\hline No. & Uraian & $\begin{array}{c}\text { Jumlah } \\
\text { (Unit) }\end{array}$ & $\begin{array}{c}\text { Harga } \\
\text { (Rp/unit) }\end{array}$ & $\begin{array}{l}\text { Nilai } \\
(\mathrm{Rp})\end{array}$ & $\%$ \\
\hline \multirow[t]{11}{*}{ A. } & Biaya Variabel & & & & \\
\hline & 1. Bahan Baku & & & & \\
\hline & Daun Gaharu & 4 & 10000 & 40000 & 2,33 \\
\hline & 2. Bahan Penunjang & & & & \\
\hline & a. Bunga Melati (gr) & 1,5 & 25000 & 37.500 & 2,19 \\
\hline & b. Kantung Bag (pcs) & 2880 & 100 & 288.000 & 16,78 \\
\hline & c. Kotak Kemasan(Kotak) & 120 & 1400 & 168.000 & 9,79 \\
\hline & d. Kemasan standing Pouch & 1680 & 1335 & 160.200 & 9,34 \\
\hline & e. Plastik Roll Transparan (cm) & 120 & 25 & 42.000 & 2,45 \\
\hline & f. Label kemasan & 120 & 500 & 60.000 & 3,50 \\
\hline & Tenaga Kerja (HOK) & 5,48 & 70000 & 383.600 & 22,36 \\
\hline \multirow[t]{7}{*}{ B. } & Total Biaya Variabel (Rp) & & & 1.179 .300 & \\
\hline & Biaya Tetap & & & & \\
\hline & a. Biaya penyusutan alat & & & 334.691 & 19,51 \\
\hline & b. Listrik (Kwh) & 64,3 & 1.467 & 94.328 & 5,50 \\
\hline & c. Kayu bakar (ikat) & 5 & 10.000 & 50.000 & 2,91 \\
\hline & d. Bahan Bakar & & & 57.575 & 3,36 \\
\hline & Total Biaya Tetap (Rp) & & & 536.594 & \\
\hline C. & Total Biaya (Variabel + Tetap) & & & 1.715 .894 & 100 \\
\hline \multirow[t]{2}{*}{ D. } & a. Produksi (Penjualan dalam negeri) & 100 & 7500 & 750.000 & \\
\hline & a. Produksi (Penjualan Luar negeri) & 140 & 25000 & 3.500 .000 & \\
\hline \multirow[t]{2}{*}{ E. } & Pendapatan & & & 4.250 .000 & \\
\hline & Keuntungan & & & 2.534 .106 & \\
\hline F. & RCR & & & & \\
\hline
\end{tabular}

Sumber: Data CV. Gaharu Plaza Indonesia, diolah, 2019

Biaya produksi usaha Agroindustri teh daun gaharu adalah sejumlah nilai yang dikeluarkan oleh pengusaha untuk kegiatan memproduksi teh gaharu. Berdasarkan input yang digunakan dalam satu kali proses agroindustri akan mempengaruhi biaya yang dikeluarkan, sekaligus penerimaan yang akan diperoleh pengusaha. Biaya produksi usaha agroindustri teh daun gaharu terdiri dari 
beberapa biaya sarana produksi seperti: Biaya bahan baku, bahan penunjang, biaya penyusutan alat dan biaya tenaga kerja yang digunakan dalam proses produksi.

Tabel 1 menunjukan bahwa total biaya produksi agroindustri teh daun gaharu untuk satu kali proses produksi berjumlah Rp.1.715.894. dengan penggunaan bahan baku sebanyak $4 \mathrm{~kg}$ daun kering gaharu. Dari jumlah bahan baku tersebut akan dapat menghasilkan output teh gaharu sebanyak 120 untuk kemasan kotak dan 120 untuk kemasan standing pouch, untuk harga satu kemasan dalam negeri Rp 7.500 dan harga satu kemasan diluar negeri sebesar $\mathrm{Rp}$ 25000. hal ini dapat disimpulkan bahwa naik turunnya biaya produksi sangat dipengaruhi oleh biaya bahan penunjang, karena bahan penunjang merupakan bahan yang sangat diperlukan dalam proses pembuatan teh daun gaharu.

\section{Pendapatan}

Pendapatan yang dimaksud yaitu pendapatan kotor. produksi yang dihasilkan oleh perusahaan untuk penjualan dalam negeri sebanyak 100 kemasan dengan pendapatan kotor sebesar sebesar Rp 750.000 dengan harga setiap kemasan Rp 7500. Selanjunya produksi yang dihasilkan untuk menjual teh gaharu ke luar negeri sebesar Rp 3.500.000 dengan jumlah kemasan 140 kemasan dan harga jual Rp 25.000.

\section{Keuntungan}

Keuntungan merupakan jumlah pendapatan yang tersisa setelah dikurangi dengan semua biaya. Dari Tabel 1 dapat diketahui bahwa pedapatan kotor usaha teh gaharu adalah Rp. 4.250.000 dengan total semua biaya produksi Rp 1.715.894. Untuk mengetahui berapa keuntungan yang didapat oleh pengusaha agroindustri teh gaharu yaitu dengan cara pendapatan kotor tersebut dikurangi dengan biaya produksi setelah itu barulah didapat keuntungan bersih usaha teh gaharu sebesar Rp 2.534.106.

\section{Efisiensi}

Efisiensi usaha agroindustri teh gaharu di CV. Gaharu Plaza Indonesia dapat diketahui dengan cara membandingkan pendapatan yang diperoleh pengusaha dengan biaya produksi yang dikeluarkan pada proses agroindustri teh gaharu. Dengan kata lain melihat Rasio penerimaan atas biaya produksi yang dikeluarkan. bahwa nilai RCR (Return Cost
Ratio) yang diperoleh pada agroindustri teh gaharu sebesar $\mathrm{Rp}$ 2,48. Hal ini dapat disimpulkan bahwa berdasarkan kriteria efisiensi usaha agroindustri teh gaharu layak untuk diusahakan, karena mempunyai koefisien atau nilai efisiensi lebih besar dari 1 .

\section{Nilai Tambah}

Nilai tambah (value added) adalah selisih antara nilai produk dengan nilai biaya bahan baku dan input lainnya, tidak termasuk tenaga kerja. Sedangkan marjin adalah selisih antara nilai produk dengan harga bahan bakunya saja. Dalam marjin ini tercakup komponen faktor produksi yang digunakan yaitu tenaga kerja, input lainnya dan balas jasa pengusaha pengolahan (Hayami et, al, 1987).

Manfaat dari analisis nilai tambah dengan menggunakan metode hayami adalah dapat diketahui besarnya nilai tambah, nilai output, dan produktifitas dan dapat diketahuinya besar balas jasa terhadap pemilik faktor produksi serta prinsip nilai tambah menurut hayami dapat diterapkan untuk subsistem lain diluar pengolahan, misalnya untuk kegiatan pemasaran (Suprapto, 2006).

CV. Gaharu Plaza Indonesia memproduksi teh daun gaharu dengan jumlah produksi berbeda-beda setiap proses produksinya dilihat dari jumlah kemasan yang habis terjual. Pada bulan November pengusaha teh gaharu melakukan proses produksi sebanyak 4 kali produksi. Untuk setiap satu kali proses produksi CV. Gaharu Plaza Indonesia dapat memproduksi teh gaharu sebanyak 240 kemasan. Penjualan teh gaharu dilakukan dengan mengikuti pameran, ekspor keluar negeri (Malaysia, Thailand, Vietnam, China dan Singapura) dan juga melakukan penjualan dengan sistem kirim ke beberapa wilayah yang ada di Indonesia.

Nilai tambah dari pengolahan bahan baku yaitu daun gaharu menjadi teh daun gaharu yang dilakukan oleh CV. Gaharu Plaza Indonesia pada penelitian ini akan dianalisis menggunakan metode Hayami, data yang akan digunakan adalah data pada bulan November 2019. Untuk melihat hasil analisisnya, akan dijelaskan pada Tabel 2. Berdasarkan Tabel 14, dapat dilihat bahwa nilai tambah dapat diperoleh dari nilai ouput yang dikurang dengan harga bahan baku dan biaya bahan penunjang, bahan baku dari daun gaharu berjumlah 4.000 gram. Sedangkan harga bahan baku daun gaharu kering untuk 1000 gram 
sebesar Rp 10.000, untuk bahan penunjang dari produksi teh gaharu berjumlah $\mathrm{Rp}$ 755.700. Nilai tambah dari pengolahan daun gaharu menjadi teh gaharu oleh CV. Gaharu
Plaza Indonesia adalah sebesar Rp. 13.269 dengan rasio sebesar $56,70 \%$.

Tabel 2. Analisis Nilai Tambah Agroindustri Teh Gaharu di CV. Gaharu Plaza Indonesia, Tahun 2019

\begin{tabular}{llr}
\hline No. & Variabel & Nilai \\
\hline I. & Output, Input dan Harga & \\
\hline 1. & Output (gram) & 5.760 \\
2. & Input (gram) & 4.000 \\
3. & Tenaga Kerja Langsung (HOK) & 5,48 \\
4. & Faktor Konversi & 1,44 \\
5. & Koefisien Tenaga Kerja Langsung (HOK/gram) & 0,00137 \\
6. & Harga Output (Rp/kemasan) & 16.250 \\
7. & Upah Tenaga Kerja Langsung (Rp/HOK) & 70.0 \\
\hline II. & Pendapatan dan Keuntungan & 10.000 \\
\hline 8. & Harga Bahan Baku (Rp/Kg) & 131 \\
9. & Sumbangan Input Lain (Rp/gram output) & 23.400 \\
10. & Nilai Output (Rp/kemasan) & 13.269 \\
11. & a. Nilai Tambah (Rp/gram) & 56,70 \\
& b. Rasio Nilai Tambah (\%) & 95,90 \\
12. & a. Pendapatan Tenaga Kerja (Rp/gram) & 0,72 \\
& b. Pangsa Tenaga Kerja (\%) & 13.173 \\
13. & a. Keuntungan(Rp) & 99,28 \\
\hline
\end{tabular}

Pendapatan tenaga kerja CV. Gaharu plaza Indonesia yang telah dikonversi menjadi HOK diperoleh imbalan Rp. 95,90 dengan rasio sebesar $0,72 \%$. Keuntungan bersih yang diterima oleh CV. Gaharu Plaza Indonesia dari pengolahan daun gaharu menjadi teh gaharu adalah sebesar Rp. 13.173 dengan rasio sebesar 99,28 \%. Pada CV. Gaharu Plaza Indonesia pengolahan bahan baku yaitu daun gaharu menjadi teh daun gaharu memiliki nilai konversi sebesar $1,44 \%$. Nilai konversi tersebut diperoleh dari bahan baku daun gaharu jenis Aquilaria malaccensis Lamk yang dibeli dari petani gaharu.

\section{KESIMPULAN DAN SARAN}

\section{Kesimpulan}

Berdasarkan hasil analisis dari seluruh rumusan masalah, maka kesimpulan dari penelitian ini adalah sebagai berikut:
1. Karakteristik pengusaha agroindustri teh daun gaharu berada pada kelompok umur 48 tahun dengan kategori produktif bekerja, lama pendidikan pengusaha 12 tahun. pengalaman pengusaha berusaha adalah 5 tahun dan jumlah tanggungan keluarga berada pada 4 jiwa. Profil usaha agroindustri teh daun gaharu CV. Gaharu Plaza Indonesia berdiri pada tanggal 16 Oktober tahun 2014 dihadapan Notaris Samharnen, S.H. MH. Skala usaha yang dilakukan adalah usaha mikro. Jumlah tenaga kerja pada proses pengolahan berjumlah 4 orang. Untuk modal usaha yang digunakan berasal dari modal sendiri.

2. Penggunaan bahan baku daun gaharu kering yang digunakan dalam satu kali proses produksi adalah sebanyak $4 \mathrm{~kg}$ dengan harga beli $1 \mathrm{~kg}$ daun kering adalah $\mathrm{Rp}$ 10.000. jadi biaya yang dikeluarkan untuk 
bahan baku $4 \mathrm{~kg}$ senilai Rp 40.000. Untuk penggunaan bahan penunjang per proses produksi adalah $\mathrm{Rp} 755.700$. penggunaan tenaga kerja pada proses pengolahan daun gaharu menjadi teh daun gaharu adalah 5,48 HOK.

3. Biaya produksi (biaya tetap dan biaya variabel) dari pengolahan daun gaharu menjadi teh gaharu adalah sebesar $\mathrm{Rp}$. 1.715.894. Pendapatan perusahaan $\mathrm{Rp}$ 4.250.000 dan keuntungan perusahaan $\mathrm{Rp}$ 2.534.106. Nilai return cost ration (RCR) perusahaan adalah 2,48. Nilai RCR > 1 menjelaskan bahwa usaha agroindustri teh gaharu menguntungkan dan layak untuk dikembangkan. Nilai tambah dari pengolahan daun gaharu menjadi teh gaharu oleh CV. Gaharu Plaza Indonesia adalah sebesar Rp. 13.269 dengan rasio sebesar 95,90\%. keuntungan bersih perusahaan $\mathrm{Rp}$ 13.173 /24gram dengan rasio 99,28\%.

\section{Saran}

Adapun saran dalam penelitian ini antara lain sebagai berikut:

1. Bagi peneliti, CV. Gaharu Plaza Indonesia merupakan pemain utama dalam ekspor produk turunan gaharu ke luar negeri. Saran dari penulis sebaiknya agar untuk peneliti selanjutnya melakukan penelitian tentang bagaimana strategi dari CV. Gaharu Plaza Indonesia bisa memasuki pasar luar negeri seperti Malaysia, Thailand, Vietnam, singapura dan China.

2. Bagi Perusahaan diharapkan dengan adanya penelitian ini mampu menambah referensi dan wawasan tentang mengembangkan usaha yang dijalankan untuk lebih efisien. Pihak perusahan sebaiknya mempertimbangkan harga jual produk.

3. Bagi pemerintah diharapkan menjadi sebuah referensi nyata bahwa adanya potensi besar dari pemanfaatan hasil gaharu.

\section{DAFTAR PUSTAKA}

Anonim. 2007. Peraturan Menteri Kehutanan Nomor P.35/Menhut-II/2007 tentang Hasil Hutan Bukan Kayu. Departemen Kehutanan. Jakarta. Aquilaria sp. di persemaian (application of phytohormone-producing rhizobacteria to improve the growth of Aquilaria sp. seedlings in the nu8rsery). Info Hutan. 7(2): 107-116.

Hayami, Y., T, Kawagoe, Y. Morooka dan M. Siregar, 1987, Agricultural Marketing and Processing in Upland Java A Perspective from A Sunda Village, CGPRT Centre, Bogor.

Mega, I. M., Suanda, D. K., Kasniari, D. N., Suena, W., Parwata, M. A. O., 2012. Formulasi Inokulan Jamur Pembentuk Gubal Gaharu pada Tanaman Ketimunan (Gyrinops versteegii). Faperta dan FMIPA Universitas Udayana: Bali.

Nasution, P. A., Batubara, R., dan Surjanto. 2015. Tingkat Kekuatan Antioksidan dan Kesukaan Masyarakat Terhadap Teh Daun Gaharu (Aquilaria Malaccensis Lamk) Berdasarkan Pohon Induksi dan Non-Induksi. Peronema Forestry Science Journal. Portal Garuda.

Soekartawi. 2010. Analisis Usahatani. UI Press, Jakarta.

Sukandar. 2010. Pengembangan HHBK Jenis Gaharu (A. malaccensis) di Provinsi.

Sumarna, Y. 2007. Budidaya dan Rekayasa Produksi Gaharu. Temu Pakar Pengembangan Gaharu. Direktoral Jendral RLPS, Jakarta.

Suprapto. 2006. Proses pengolahan dan nilai tambah. Penebar Swadaya, Jakarta. 